\title{
Executing a business model change: identifying key characteristics to succeed in volatile markets
}

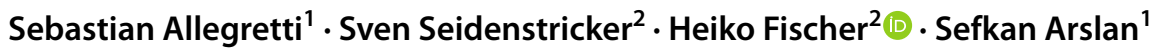

Received: 7 September 2020 / Accepted: 18 February 2021 / Published online: 27 February 2021

(c) The Author(s) 2021

\begin{abstract}
The world is changing, and with it comes the requirement that enterprises change to survive in today's volatile markets. However, the change does not just include launching a new product on the market but also changing the business model of the whole organisation. To sustain in today's fast-changing markets, companies have to detect new market opportunities on time, assess them and find a way to incorporate the most beneficial opportunities into their business. Without this awareness that a company must change with the changing market, it risks losing its significance in the market. Both the change of the business model and the change of the organisation are needed to succeed in the market. An outstanding example of such a company is Netflix. They have successfully changed their business model twice: first, from an online-DVD-rental service to a streaming provider and then, to a content provider. They were aware of upcoming new technologies on-time, evaluated them and planned the implementation in the market while the old technology was still profitable. The present work outlines the major changes in Netflix's business model and how they managed the change process successfully.
\end{abstract}

Keywords Business model $\cdot$ Business model change $\cdot$ Business model canvas $\cdot$ Successful change $\cdot$ Alterable company $\cdot$ Adapt market opportunites

\section{Introduction}

The rapid digitalisation in today's world offers new opportunities and threats; it is breaking down traditional barriers and making access for new market entrants easier (Ibarra et al. 2018). For this reason, researchers point out the importance of rethinking the business model to gain a competitive advantage (Ibarra et al. 2018; Rachinger et al. 2019). Despite this, companies are still more focused on product and service innovations and are minimally engaged with their business models (Hossain 2017).

A famous example of a company that failed to adapt to new market conditions and its business model is Toys "R" Us. They missed the changes in the market and therefore, did not continue to address their customer's needs. Instead of taking digitalisation into account and developing new

Heiko Fischer

heiko.fischer@mosbach.dhbw.de

University of Applied Sciences Ulm, Ulm, Germany

2 Baden-Wuerttemberg Cooperative State University Mosbach, Bad Mergentheim, Germany value propositions for the customers, as Amazon did, Toys $\mathrm{R}$ Us insisted on their traditional business model. This is how Toys R Us went bankrupt in 2017 (Albanese 2017).

This example shows the immense importance of Business Model Change (BM Change) for a firm to sustain in the market. Nevertheless, profound insights about motivators, facilitators and hindrances are still missing to successfully execute a BM Change. (Witschel et al. 2019). For this reason, the present work uses the example of Netflix to show how a successful BM Change can look like.

Netflix can be seen as an outstanding example of BM Change since they have already successfully changed their business model two times: Founded as an online-DVD-rental service, they changed their business model for the first time when they decided to become a streaming provider. Later they continued adjusting their business model and are now both a streaming provider and a producer of original content. They have succeeded in changing an already successful model into a globally successful company (Netflix Inc 2020).

To understand how this outstanding success was possible, the present work analyses Netflix's business model over time. Using the Business Model Canvas (BMC), the 
three phases-founding, first, and second BM Changeare presented in detail, differentiated into the nine building blocks of the BMC. This approach shows what a successful business model change looks like. The work focuses on key characteristics in the Netflix change process, which explains the company's success.

\section{Business model change as the key to success}

There are various definitions of the term business model and different design approaches. A well-known explanation is that a business model "describes the rationale of how an organisation creates, delivers, and captures value" (Osterwalder et al. 2010). Teece (2018) follow this explanation and state that it "describes an architecture for how a firm creates and delivers value to customers and the mechanisms employed to capture a share of that value."

Due to the various theoretical approaches, the origin of the term, business model, cannot be clearly identified. An early approach stems from Peter Drucker, who formulated "The Theory of the Business." In this, he describes certain assumptions about business models without mentioning the term. These assumptions relate to customers and clients, the market, the company itself and other issues important for its existence and growth. Based on Drucker's assumptions, Magretta explains the business model as a story that describes the main tasks of a company to create a value chain for the customer (Ovans 2015).

One of the first definitions of this concept of 'business model' is by Magretta in 2002, which provided the basis for other researchers to further develop the term (Nielsen and Lund 2014). Business models are still in a constant state of change and therefore, cannot be absolutely defined. Particularly in the last decade, the trend towards professionalisation in business models has become visible in the increasing number of publications (Cuc 2019). The researches underline that business models are the basis for competitiveness, firm performance and innovations (Witschel et al. 2019).

Recent literature emphasises the importance of BM Change, which can be seen "as the process by which management actively alters the intra-organisational and/or extra-organisational systems of activities and relations of the business model in response to changing environmental conditions" (Witschel et al. 2019). This definition shows that BM Change is the process that can lead to a business model innovation (BMI). Accordingly, both terms are closely related.

In summary, there are four distinct research streams. The first stream includes the phenomenon of BMI and delivers definitions and conceptualisations. It shows the dynamics of a business model and how companies can innovate it.
The second research stream shows BMI as an organisational change process. Thus it presents, for instance, capabilities, techniques, and stages to successfully manage the process that leads to a BM Change. Moreover, the third stream focuses on the outcome of the change: the new innovative business model. The fourth and last research stream outlines the consequences of the BMI and therefore, the BM Change. It summarises the effects of the change on the firm's performance (Foss and Saebi 2017).

BM Change possesses certain triggers and environmental dynamics, which can be classified into three triggers. The first trigger is a regular environmental change that is highly predictable. This leads to a slow and incremental change. The second trigger is environmental competitiveness. This involves changing competitive demands and high-velocity environments. Typically, the pressure for higher efficiency or lower prices is associated with this trigger. Lastly, the environmental shift is the trigger that leads to the most dramatic and discontinuous change of a company's environment. Disruptive technologies, new competitors, and regulatory or political changes lead to a profound change. An environmental shift is hardly predictable and leads to fundamental changes not only in the business model but in the entire organisation as well (Ode and Wadin 2019).

As a consequence, a successful BM Change requires the observation of the firm's environment. Opportunities and threats have to be discovered and translated into new business models. Typically the development of a business model is a continuous learning process accompanied by experiments and adjustments. (Rissanen et al. 2020).

The Business Model Canvas has a possibility to visualise the development and change of a firm's business model. However, there are plenty of alternatives to the BMC. These usually differ in the number of categories considered; typically, this is between three and nine categories (Seidenstricker et al. 2018; Seidenstricker and Ardilio 2017).

In order to visualise the changes in Netflix's business model, this working paper utilises the BMC due to its wide coverage of different areas and the resulting greater variety of analysis options. The main advantage of the BMC lies in a clear and concise design, the targeting of customer needs and the focus on the main factors (Young 2018). Since the BMC does not take competition into account, a separate chapter is devoted to the analyses of changes in competition. Figure 1 (below) illustrates the BMC with its nine building blocks (Osterwalder et al. 2010) and divides it into four sections (Cinergix Pty. Ltd. 2019). Customer Segments, Channels and Customer Relationships make up the market view. The enterprise view consists of the Key Activities, Key Resources and Key Partners. Cost Structure and Revenue Streams lend the financial view. Since the Value Proposition is located in the middle of the $\mathrm{BMC}$, it receives its own view: the value proposition view (Figs. 2, 3, 4, 5, 6). 


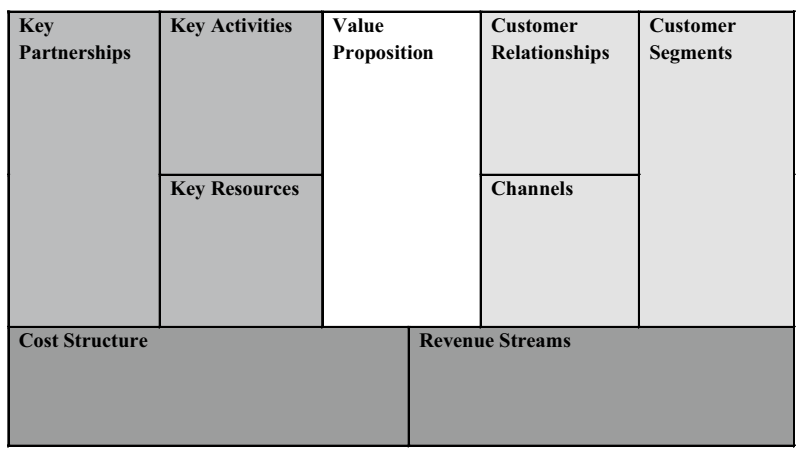

Fig. 1 Business model Canvas separated into four views

The process between changing an existing model and creating a new one clearly differs. Since existing business models are designed to be stable, it is particularly challenging to change them. It is, therefore, advisable for companies to follow change processes according to certain patterns. Since both the motives and the boundary conditions of a BM Change differ from case to case, there are also various approaches to describe the process of change. One of these approaches is the so-called business ecosystem approach, which brings about a change in the model while considering changes in the market (Heikkinen 2014).

The success of these BM Changes can be measured using key performance indicators (Tyler 2020). In general, there are the following core capabilities to successfully change business models: sensing opportunities and threats, making timely and market-oriented decisions, and reconfiguring the organisational resource base (Witschel et al. 2019).
Fig. 2 Netflix roadmap

Fig. 3 Changes in Netflix's business model over time: value proposition view

Fig. 4 Changes in Netflix's business model over time: market view

\begin{tabular}{|c|c|c|c|}
\hline 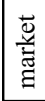 & $\begin{array}{l}\text { Costumers have to rent their } \\
\text { movies and return them at a } \\
\text { retail shop }\end{array}$ & $\begin{array}{l}\text { Progressions in the internet } \\
\text { technology benefit video- } \\
\text { on-demand services }\end{array}$ & $\begin{array}{l}\text { Need of content to match user } \\
\text { preferences }\end{array}$ \\
\hline 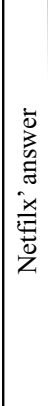 & $\begin{array}{l}\text { 1997: Foundation of Netflix; } \\
\text { Netflix as Online-DVD-Rental } \\
\text { Service with home delivery } \\
\text { - First Pay per Rental, later as } \\
\text { Subscription model } \\
\text { - Personalized } \\
\text { Recommendations } \\
\text { - Easy order and return process } \\
\text { - No late fees }\end{array}$ & $\begin{array}{l}\text { 2007: Netflix primarily as } \\
\text { Streaming Provider } \\
\\
\text { - Subscription model } \\
\text { - } \quad \text { Personalized } \\
\text { Recommendations } \\
\text { - Support of different } \\
\text { devices } \\
\text { - Unlimited streaming }\end{array}$ & $\begin{array}{l}\text { 2013: Netflix as Content } \\
\text { Producer } \\
\text { - 2013: Premiere of Netflix' } \\
\text { first Original content "House } \\
\text { of Cards" } \\
\text { Over } 1,500 \text { Netflix Originals } \\
(04 / 2020) \\
\text { - Offline Streaming } \\
\text { - 2019: In total over } 13,000 \\
\text { titles, in the US more than } \\
5,000 \text { available }\end{array}$ \\
\hline
\end{tabular}
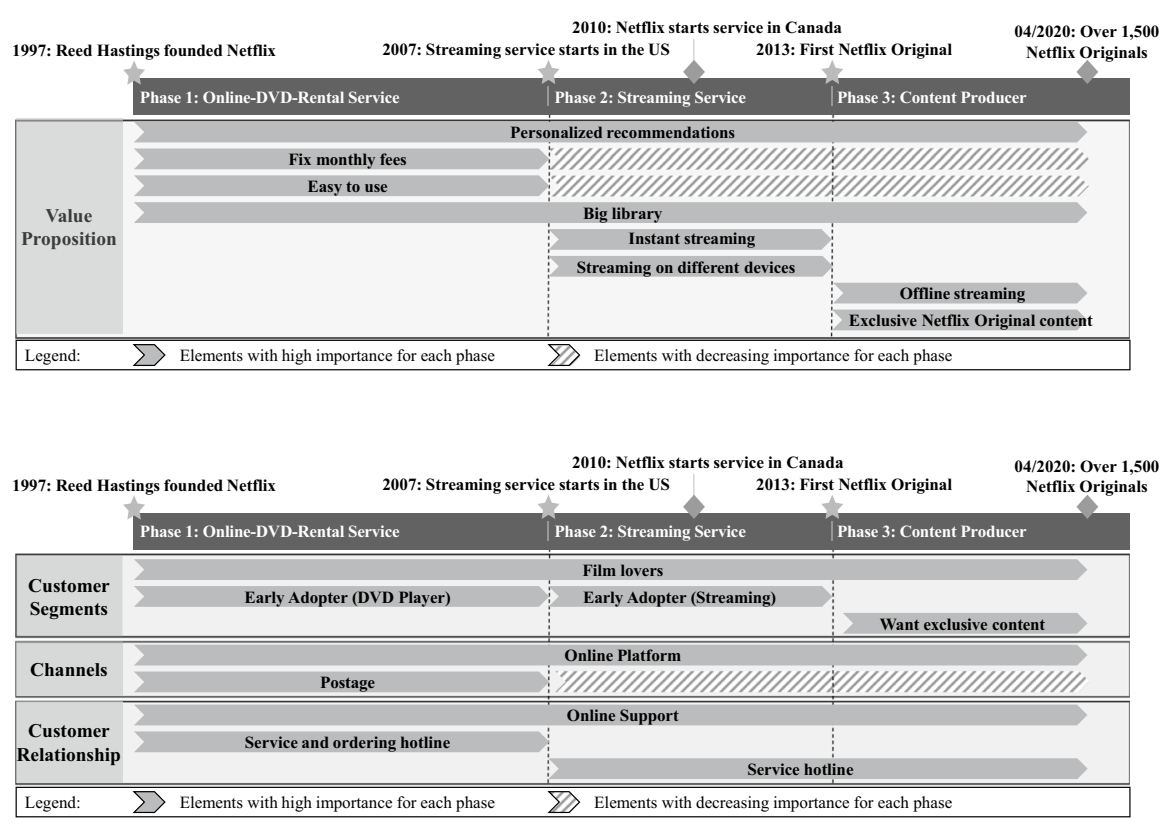
Fig. 5 Changes in Netflix's business model over time: enterprise view
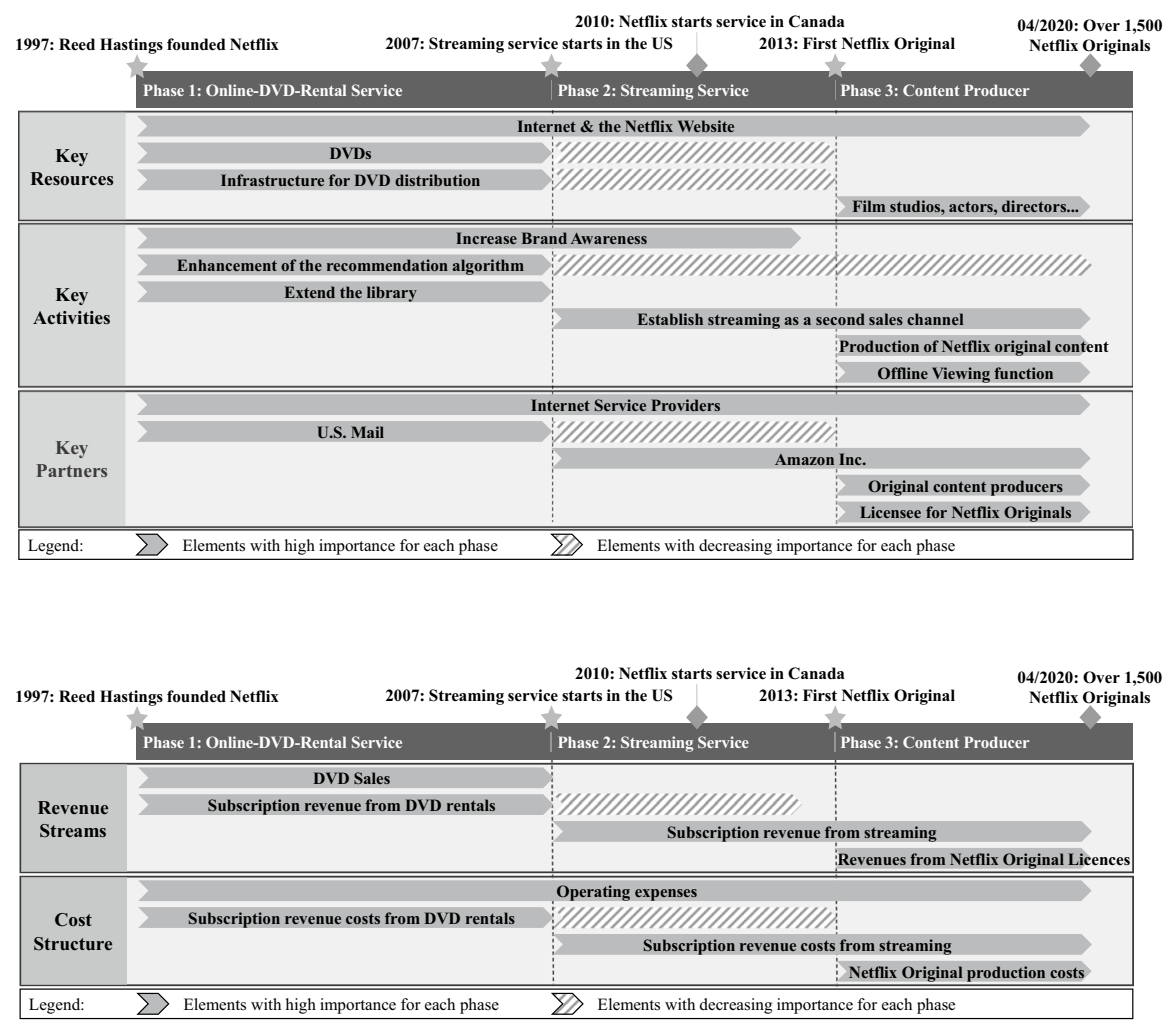

Fig. 6 Changes in Netflix's business model over time: financial view
12,000 movies and TV episodes to stream instantly, plus about 100,000 DVDs available through the home delivery service (Murph 2008). Because of Netflix's success in the U.S., the board of directors approved the decision to expand internationally. Firstly, in Canada and later in other parts of the world (Netflix Inc 2020). In an interview, Reed Hastings states that every market with access to broadband is attractive for Netflix (Frommer and Blodget 2011). In order for Netflix to sustain in the future, it is necessary to stop being purely a distributing middleman and start providing exclusive content made to meet the desires of their subscribers (Yglesias 2013). Therefore, in 2013 Netflix premiered their first Netflix Original Series, "House of Cards", followed by a continuously rising number of exclusively produced movies, documentaries and TV shows. The increase in original content is also to prevent being dependent on licensed content; instead, the aim is to be able to maintain their subscribers with company-owned shows (Steel 2015) In December 2018, for the first time, the amount of Netflix Originals reached $51 \%$, surpassing the number of licensed shows in their library. This shows its aim to become a content producer as well as stay committed to the core of their business model (Burks 2019).

Netflix's success in content production is seen in its growing role at the annual Oscars. In 2014, Netflix managed to get their first nomination for the documentary film "The Square"; however, it did not win an award (Clark 2020). The documentary film "The White Helmets" was 
the first success at the Academy Awards in 2017, followed by further successes in the following years (Reid 2017).

With 24 nominations, Netflix was the studio with the most nominations in this year's Academy Awards, showing it's increasing role as a content producer. Of these, the film "Marriage Story" won the Oscar for best supporting actress, and the documentary "American Factory" won the Oscar for best documentary feature (Solsman 2020).

\subsection{Detailed view of Netflix's business model change}

The following charts show the changes in Netflix's business model during their three phases of the BMC-featured building blocks. The charts are divided into value proposition, market, enterprise and financial views.

\subsection{Value Proposition}

The generated value is a result of many different components. The main factor spanning all three phases in Netflix's business model is the algorithm for personalised DVD recommendations. This is based on the actual watchlist of every subscriber instead of recommendations from others, leading to a more personalised experience (Netflix Inc 2002a). Another value constantly generated over all three phases is made by the large selection offered. In 2019, subscribers were able to choose from over 13,000 titles (Lovely 2019), including 1,100 Netflix Originals (Elliott 2019). Apart from these, the value Netflix created differs in each phase. During its time as a DVD rental company, Netflix's value was also created by its fixed monthly fees, meaning there was no late fee. Additionally, the ease and convenience of the rental and return process (Netflix Inc 2002a). After the first change to a primarily video-on-demand provider, these two factors became less important. Instead, Netflix's value became generated by the instant streaming of titles and the crossplatform compatibility, which allows streaming on different devices such as mobile phones, gaming consoles, tablets and televisions (Falcone 2009; Netflix Inc 2011). Due to further technological progress over time and, thus, growing competition, Netflix has been forced to find new ways to create value for its subscribers. Hence in 2013, Netflix offered its first Netflix Original Series, "House of Cards," exclusively on their service. Subsequently, Netflix has continued focusing more and more on original content instead of licensing (Roettgers 2013). Additionally, in 2016, Netflix introduced the offline viewing function to allow watching certain movies and series without internet connection (Netflix Inc 2018).

\subsection{Customer segments}

Initially, Netflix defined their target group as "[...] a classical early adopter: predominantly affluent, technologicallysavvy, and male. [In 2002,] women made up more than half of [its] subscribers [...]" (Netflix Inc 2002a). Already, in the early stages of Netflix's business model, the company extended its target group from early adopters to people interested in movies. Particularly, consumers who prefer to watch movies at home used Netflix's subscription service to have DVDs sent directly to their houses (Netflix Inc 2002a). With the step into streaming, the target group for Netflix has also changed from early adopters using DVD players to early adopters utilising video-on-demand services (Netflix Inc 2007). As streaming has become more common these days, Netflix's target audience has also changed from early adopters to people who want exclusive content (Netflix Inc 2013). As well as the changing audiences, Netflix attracts affine movie-watchers throughout all three phases.

\subsection{Channels}

Netflix's business model as an online-DVD-rental company required two crucial factors. First, an online platform to place orders and, second, the mailing route to send the DVDs. These DVDs arrived with a prepaid return envelope, making the process easy and convenient (Netflix Inc 2002a).

Netflix's changes in their business strategy in order to become a video-on-demand provider led to an increase in streaming instead of distributing DVDs and, therefore, a decrease in the importance of mailing routes (Netflix Inc 2013).

\subsection{Customer relationship}

Despite the past changes in Netflix's business, the way Netflix interacts with subscribers has barely changed. The company's online orientation means that customer support during all three phases is provided primarily on the website. Even in the early stages of Netflix, subscribers could solve most of their problems on a self-service basis, "[...] such as the ability to report and correct most shipping problems" (Netflix Inc 2002b). Also, for further communication, customer support seven days a week via e-mail and phone is provided (Netflix Inc 2002b).

\subsection{Key recourses}

Based on Netflix's prior business model as an online-DVDrental company, the key recourses are the website to place orders, the DVDs themselves, and the infrastructure to distribute these items within one to two days (Netflix Inc 2002a). 
With the start and development of Netflix's streaming service, DVDs, and the necessary infrastructure lost their importance, while the Internet and website gained importance. Therefore, Netflix's most important key recourse became the Internet and their website. Later, movie studios, directors and actors were incorporated into the list of key recourses due to the increasing focus on Netflix Originals (Netflix Inc 2018).

\subsection{Key Activities}

Crucial for a new company like Netflix, in the interest of competing with companies like Blockbuster, was raising brand awareness. Hence, Netflix put a lot of effort into marketising their service on many different channels such as "[...] online promotions, advertising insertions with most leading DVD player manufacturers, and promotions with electronics and video software retailers" (Netflix Inc 2002a). Furthermore, Netflix put great interest in continuously improving its recommendation algorithm. For that reason, in 2006, Netflix started a contest for developers to improve the recommendations algorithm and offered a \$1 million prize (Jackson 2017). In the second phase, it became more and more relevant for Netflix to establish streaming as the second sales channel (Netflix Inc 2007) and also keep raising its brand awareness, especially in the international market (Pepitone 2011). Netflix established themselves domestically as well as internationally, which is why one key activity of Netflix today is to offer exclusive content to differentiate themselves from the mass of streaming providers (Roettgers 2013). A second key activity was to keep improving their service by offering functions like offline streaming (Netflix Inc 2018).

\subsection{Key partners}

The strong reliance and necessity of the Internet throughout all three phases of Netflix's corporate history solidifies the fact that Internet service providers are considered as one of the key partners for Netflix's success. Initially, the U.S. Parcel Service was also considered one of the most important partners due to the home delivery service. With the declining importance of the online-DVD-rental service, the U.S. Parcel Service also lost its importance (Netflix Inc 2013).

In 2009, in order to handle the increasing data traffic caused by streaming, Netflix started outsourcing their data centres to the public cloud using Amazon Web Services (AWS). In 2016, Netflix closed the last self-owned data centre. "The migration improved Netflix's scalability and service availability, and the velocity by which the company could release new content, features, interfaces and interactions. It also freed up the capacity of engineers, cut the costs of streaming, drastically improved availability and added the experience and expertise of AWS" (Macaulay 2018), making Amazon a key partner in streaming.

With the step to producing its own content, Netflix also has to partner up with producers for their original content. Therefore directors, actors, etc., became essential partners (Netflix Inc 2018).

\subsection{Revenue streams}

In 1998, when Netflix started its service, the revenue stream consisted of two elements: the sales of DVDs, which became insignificant early on, and the subscription model for renting movies. This revenue stream underwent a rapid growth "[...] from $\$ 74.3$ million in 2001 to $\$ 150.8$ million in 2002 , representing a 103\% increase" (Netflix Inc 2002b).

With the shift of focus onto streaming, the main revenue source also changed. In 2013, 75\% of Netflix's domestic revenue was made by streaming, while the other $25 \%$ were generated by DVD rentals. This change is also visible in the number of subscribers to each model. In 2013, Netflix's DVD service had about 7 million domestic subscribers, while the number of streaming subscribers in the U.S. was at about 33 million. Five years later, in 2018, only 2.7 million subscribers used the DVD service, while 58.5 million subscribed to the streaming service in the U.S., showing a clear trend towards Netflix's business (Edspira 2019).

\subsection{Cost structure}

Netflix's cost structure is primarily made up of the costs for operating expenses and costs of revenues (Netflix Inc 2002b). Operating expenses include technology and development costs (e.g. to improve the recommendation algorithm), marketing costs, general and administrative expenses (e.g. payrolls), stock-based compensations for employees and fulfilment, which includes expenses surrounding logistical service, and more (Netflix Inc 2013). Naturally, these operating costs are present in all three phases of Netflix's business model. Cost of revenues, on the other hand, include, for example, the subscription revenue costs and cost of sales revenue. Under subscription revenue costs, Netflix defines revenue-sharing costs, or that Netflix pays a sharing fee for every DVD shipped to a subscriber, amortisations of DVD costs and intangible assets related to equity issued to studios, and, finally, postage and packaging costs (Netflix Inc 2013).

These costs were especially prominent during the first phase of Netflix's 'high.' With the change to streaming, the costs due to shipping of DVDs diminished and, instead, Netflix started to pay for streaming licenses and per view (Netflix Inc 2013). The last change in the cost structure occurred in 2013 when Netflix decided to enter the original content market; Netflix's strategy change to more original content instead of licensing also led to original content expenses. 
In 2019, Netflix spent roughly $\$ 10.5$ billion on its original content (Schedeen 2019). This increase is necessary due to the rising competition of companies like Disney, Amazon, Apple, and more, offering exclusive content in order to support their services (Spangler 2019).

In conclusion, Netflix underwent two main BM Changes. The first one beginning in 2007, which shifted the focus from online-DVD-rentals to a global video-on-demand provider. And the second began in 2013 with the premiere of Netflix's first original series, "House of Cards," which shifted their reliance from licensed content to production. The effects of the change vary dramatically depending on the building blocks. In particular, the elements of value created underwent the biggest changes.

\subsection{The development of Netflix's key figures throughout the business model change}

In order to obtain an overview of the economic development of Netflix, this chapter focuses on the trend of key figures over time. Figure 7 focuses on the development of employee numbers and how these are affected by the changing business model.

When Netflix went public in 2002, its official number of total employees was roughly 500. Out of these, 381 employees were full-time workers, while 114 were part-time and temporary workers. In the annual report, Netflix stated that these part-time and temporary workers are used "[...] primarily in Fulfillment Operations, to respond to fluctuating demands for DVD shipments" (Netflix Inc 2002b). Due to the increasing demands of Netflix's delivery program and the launch of the streaming service, the need for employees increased greatly compared to 2002 . As a result, the number of Netflix's employees rose greatly until 2010. In particular, the number of temporary employees remained consistently high, leading to a ratio of about one-to-one of permanent-totemporal employees. Marketing also saw the highest number of temporary employees in the corporation's history.

Only in 2010 did the number of temporary employees begin to decline again. In the annual report of 2011, the company explains this: "Our use of temporary employees has decreased significantly due to decreased DVD shipments in 2011, as well as increased automation of our shipment centres" (Netflix Inc 2011). From 2013 on, the number of permanent employees increased every year. This rise was mainly caused by the growing international orientation of the company and the decision to produce its own content. The absence of information on temporary employees from 2018 onwards is due to their non-publication in the annual report. It is also interesting to analyse the changes in the
Fig. 7 Development of Netflix's total employees

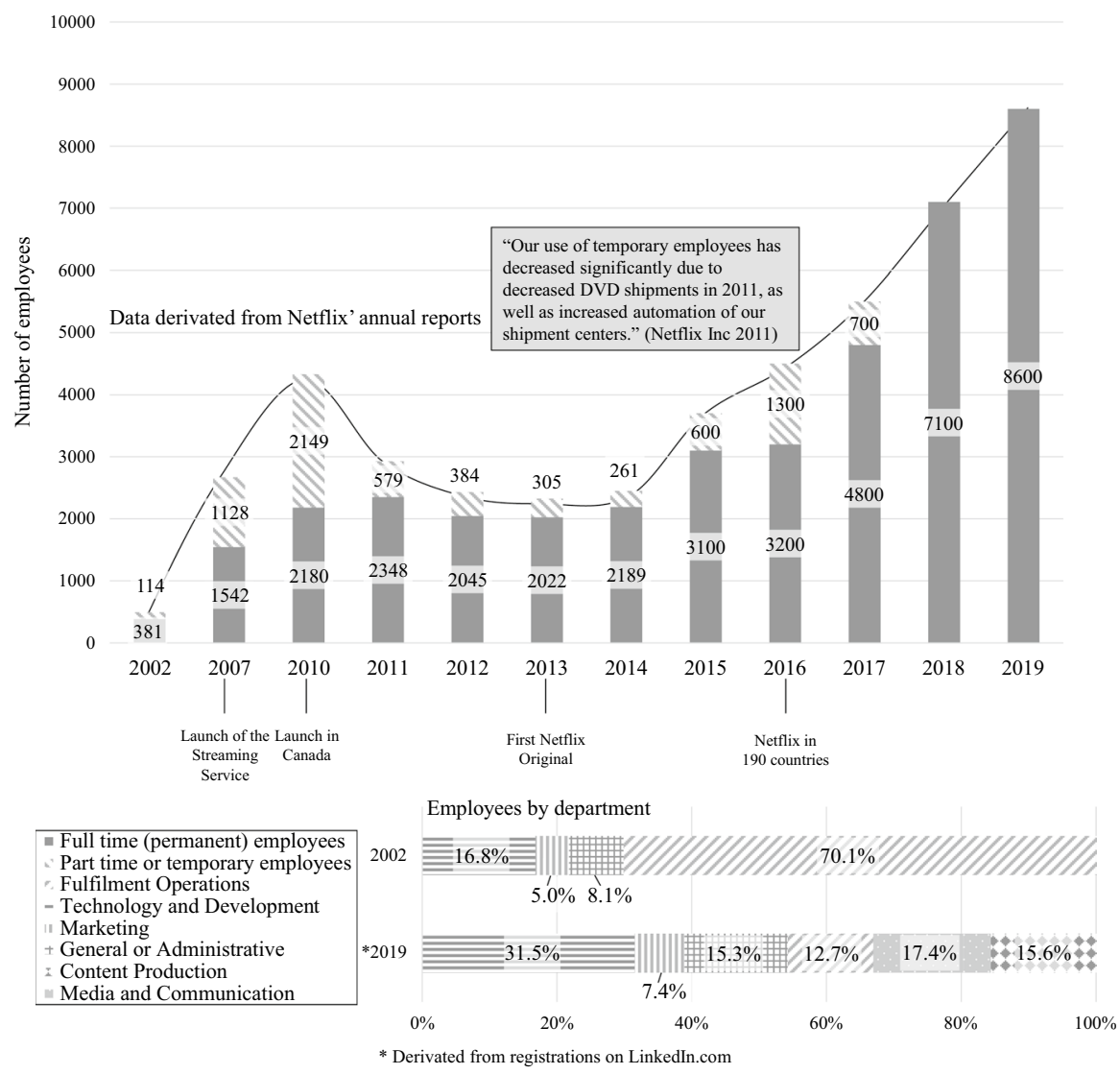


distribution of employees across departments due to the BM Change. Since Netflix only published the distribution of employees by department in their 2002 annual report, a comparative figure for 2019 is based on LinkedIn registrations by department in per cent.

According to the pie chart, the majority of the employees in 2002 were employed in the Fulfilment Operations department. These employees are primarily responsible for the activities related to the DVD rental process. A further $16.8 \%$ are responsible for technology and development and work on improving services, problem-solving, and other processes. The remaining 5\% work in marketing and $8.1 \%$ are responsible for general and administrative tasks. (Netflix Inc 2002b).

The introduction of the new business model led to the conclusion that changes in the company structure were also necessary. Due to the necessary changing competencies, the distribution of employees among the departments was also affected.

With the shift towards streaming and content production, positions in fulfilment became less important, dropping to about $13 \%$. Caused by the focus on streaming and content production, the Technology and Development department increased to $31.5 \%$, as well as a new subsection, Media and Communication, which reached about $17.4 \%$. Employees focused on content production made up another $15.6 \%$ of Netflix's total employees (LinkedIn 2020).

With the internationalisation of their service, the need for more marketing and general/administration-related staff also increased. The following Fig. 8 focuses on the development of the annual revenue from 2002 to 2018 and classifies these by income source (Figs. 9, 10).

In 2002, Netflix's income was solely generated by physical DVD rentals. With a revenue of about $\$ 150$ million
Fig. 8 Netflix's revenue growth over time

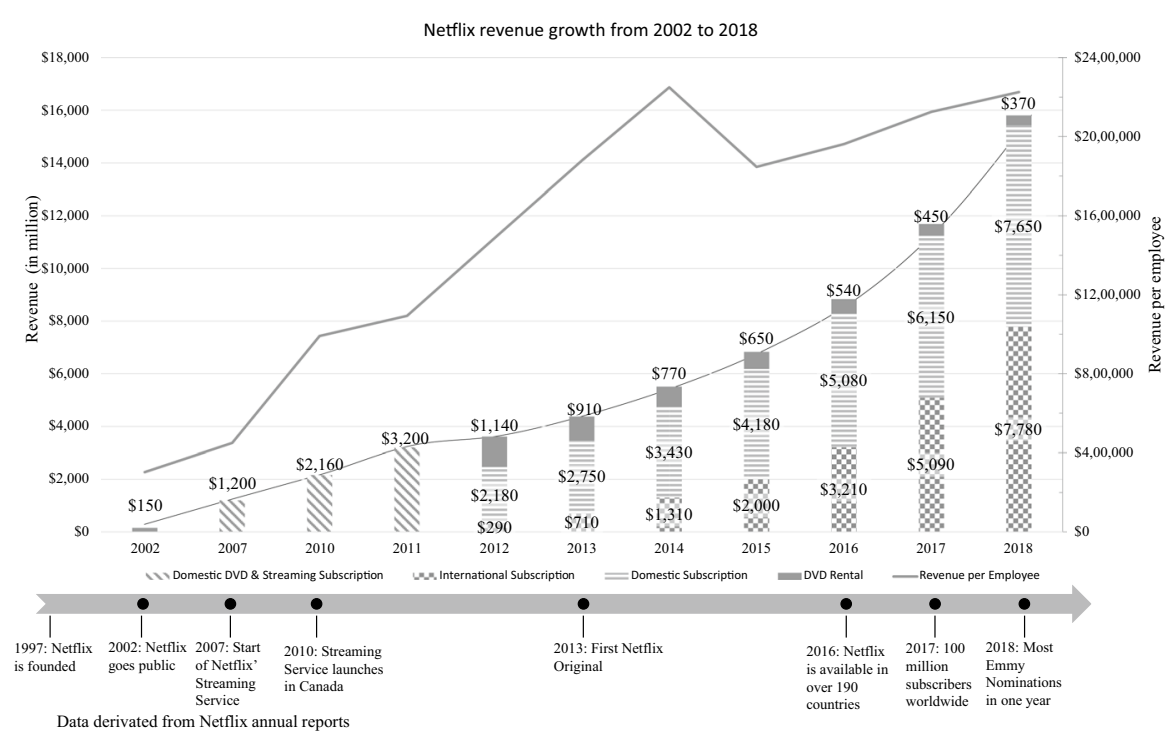

Fig. 9 Netflix's biggest competitors

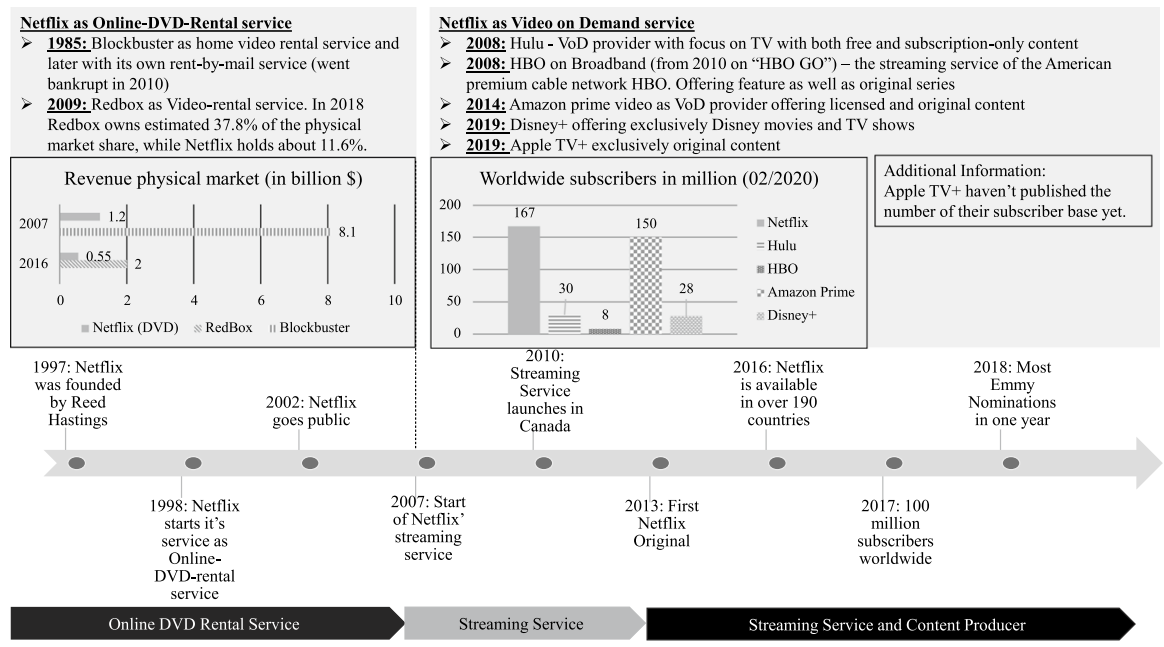


Comparison of lobbying expenses (2019)

\begin{tabular}{|l|c|c|}
\hline \multicolumn{1}{|c|}{ Company } & $\begin{array}{c}\text { Total lobbying expenses } \\
\text { (in million \$)* }\end{array}$ & $\begin{array}{c}\text { Lobbying expenses in } \\
\text { relation to the revenue }\end{array}$ \\
\hline Amazon & 16.8 & $0.0060 \%$ \\
\hline Facebook & 16.7 & $0.0236 \%$ \\
\hline Google & 11.8 & $0.0073 \%$ \\
\hline Apple & 7.4 & $0.0028 \%$ \\
\hline Disney & 4.6 & $0.0066 \%$ \\
\hline Netflix & 0.85 & $0.0042 \%$ \\
\hline
\end{tabular}

*Data derivated from opensecrets.org entries

Fig. 10 Comparison of lobbying expenses in 2019

(Netflix Inc 2002b) and roughly 500 employees (including part-time workers; Netflix Inc 2002b), the revenue per employee was approximately $\$ 300,000$, the lowest in all their statistics. Despite the strong increase in revenue, the key performance indicator, revenue per employee, was only increasing slightly due to the growth in the number of employees. Furthermore, a look at the revenue curve shows the importance of streaming for Netflix's business success. The majority of revenue was generated through domestic and, later, mainly international streaming. In 2018, for the first time, international turnover exceeded the streaming revenue made in the US. With a cumulative turnover of $\$ 15.8$ billion, Netflix generated more than a hundred times its 2002 figures (Netflix Inc 2018). The characteristic bend in the revenue per employee curve in 2013 reflected the phase when the company turnover was high and the number of employees particularly low due to increasing automation in the fulfilment area (Netflix Inc 2011). The revenue per employee curve then settles at around $\$ 2$ to $\$ 2.5$ million per employee. The reason for this is that the number of employees rose in line with the revenues.

\subsection{The change of Netflix's main competitors over time}

The profound change in Netflix's business model led to a change in the competitive environment as well. To illustrate the changing competitive environment, this chapter compares the different competitors to Netflix in the respective phases. The key findings are summarised in the following figure.

As already stated, Netflix managed to become one of the world's most successful video-on-demand providers. But in the early stage of Netflix's business, they proved to be ambitious enough to survive the strong competition. As an onlineDVD-retailer, Netflix's main competitors were Blockbuster and the non-franchised DVD retailers; later, RedBox also entered the fray. Blockbuster, which was founded in 1985, was known to be Netflix's main competitor. The difference between Blockbuster and Netflix can be narrowed down into two areas. The distribution channels and the recommendation process. While Netflix offered its service online and delivered the DVDs directly to customers' homes, Blockbuster focused on local franchise shops to distribute their DVDs and games. In 2004, Blockbuster also began offering the home-delivery of DVDs to poach customers from Netflix (Pogue 2005). In terms of the recommendation algorithm, the difference between the two competing companies was that Netflix delivered individual suggestions to the 'watch' preferences of their subscribers (Netflix Inc 2002a). Thus, even though Blockbuster recorded sales of $\$ 8.1$ billion in 2007 , while Netflix generated $\$ 1.2$ billion, by 2010 , the company went bankrupt (Ash 2020). With the founding of Redbox in 2009, another main competitor entered the market of physical DVD rentals. The main difference to Blockbuster and Netflix was that Redbox operated automated kiosks for DVD \& game rentals and returns. Customers were able to rent DVDs and games from over 41,500 self-service kiosks. Starting in 2018, Redbox began offering on-demand streaming without the need for a subscription (Redbox 2020). In 2018 Redbox owned an estimated $37.8 \%$ of the DVD, game and video rental market share in the US, while Netflix held about $11.6 \%$ (Graham 2018).

With the changing focus towards streaming, Netflix faced a new competitive environment with different competitors. The main competitors are divided into two categories. The previously established competitors and upcoming threats. Among the already established competitors were Hulu, Amazon Prime and HBO, while the category of upcoming threats included Apple TV + and Disney + . Almost simultaneously, with the introduction of Netflix's streaming service, Hulu and HBO also entered the video-on-demand market. Clearly different to Netflix, Hulu focused on TV streaming, with both free and subscription-only content. In contrast, the streaming service of the American premium cable network, HBO, focused more on HBO originals like "Game of Thrones" and other feature titles. After the introduction of Amazon's streaming service in 2014, they rapidly became Netflix's main competitor. With 150 million subscribers, Amazon Prime Video is currently the biggest competitor to Netflix, with its 167 million subscriber base (Littleton 2020). Similar to Netflix, Amazon Prime offers licensed as well as original content. With the increasing importance of streaming services, more and more companies have decided to enter the fray. These companies include Apple and Disney, comprising the two main participants in the category of upcoming threats. With Apple TV + and Disney +, these two big companies started to offer exclusive original content to their subscribers. Disney managed to acquire 28 million subscribers in the first year (Littleton 2020). In comparison, Apple has not yet published any official figures on their subscriber base. 


\subsection{Changes to Netflix's lobbying strategy}

Besides the importance of competing with other competitors, it is also crucial to ensure a beneficial environment for one's business model. Therefore, it often becomes necessary to be active in lobbying.

In order to put the lobbying expenses of Netflix in relation to other tech companies, the graphic shows the absolute and relative revenue dedicated to lobbying expenses of selected businesses in the US. A look at the absolute expenses shows very clearly that Netflix spent about $\$ 850,000$, the least compared to the other five companies. Amazon and Facebook, on the other hand, had the highest absolute expenses for lobbying with $\$ 16.8$ million and $\$ 16.7$ million. Even though Google, Apple and Disney are behind Amazon and Facebook, their expenses are still significantly higher than Netflix's. This difference between Netflix and the other companies decreases greatly when the absolute expenses are put into relation to the annual revenue. With about $0.0042 \%$, Netflix's relative expenses are quite similar to the other businesses. Only Facebook stands out for its high relative spending of about $0.0236 \%$ compared to annual revenue.

What is interesting for this research paper is the change of focus in the use of these funds. With the introduction of original content and the globalisation of Netflix, also the destination of lobbying funds has changed. Up until the end of 2018, Netflix was a member of the Internet Association, which to date includes Google, Facebook and Amazon, and then became the newest member of the Motion Picture Association of America (MPAA; Keegan 2019). While the Internet Association "[...] exclusively represents leading global internet companies on matters of public policy" (Internet Association 2020), the MPAA focuses on supporting the "[...] film, television, and streaming industry around the world" (MPAA 2020). The reason behind this change varies. One of them is the increasing importance of creating original content; thus, which made the MPAA a better fit for Netflix.

Another reason is the rising internationalisation of Netflix. Nowadays, Netflix is active in more than 190 foreign countries, where most of Netflix's growth lies. Due to this, the necessity for internationally-oriented lobbying increased drastically. "The MPAA's global reach gives Netflix a bargaining advantage on issues from Latin American tax policy to new European laws regulating streaming companies" (Keegan 2019), making the MPAA a more suitable partner for their lobbying funds.

Today, Netflix employs approximately 30 full-time public policy staff, four of them work national offices and the others in international offices (e.g. in Germany, France, Brazil, Mexico, India, Australia and Korea). The goals of Netflix's lobbying are focused on the taxation of digital services, new regulations, such as those concerning AI, and others (Keegan 2019).

\section{Discussion}

In order to narrow down how Netflix was able to change its business successfully, this discussion will list some characteristic points in Netflix's strategy to find a possible answer to this question. First, it becomes clear that Netflix is a flexible company that doesn't rely too much on their previous success (in contrast to Toys "R" Us). This helped Netflix decide to change their business model, even though their DVD rentals increased constantly. The fact that Netflix does not allow themselves to be distracted by their early success but is willing to change shows its flexibility and openness to change, as previously mentioned. In an interview with Reed Hastings, he mentioned early on that Netflix is not limited to DVD rentals but is open to implementing video-on-demand once the necessary technology was mature enough. "We want to be ready when video-on-demand happens. That's why the company is called Netflix, not DVD-by-Mail" (Hastings 2005). A lack of flexibility and openness can lead even successful companies to lose importance or even disappear completely. Examples of this are Blockbuster, which failed to satisfy the need for streaming and, therefore, went bankrupt (Ash 2020). Another example is the former tech giant, Nokia, which reacted too late to the trend towards smartphones and thus lost their strong market position to their competitors (Bhasin 2018). In addition, Netflix does not stick strictly to earlier statements. So, despite earlier statements that Netflix has no interest in original content, they revised these and entered the content production arena when a good opportunity arose, with their first original, "House of Cards" (Fritz 2011). Another reason for the successful transformation of Netflix is that they did not completely dissolve their previous profitable DVD rental business model, but continued to run it in parallel with the new business model. This made it possible for them to build up the streaming service without having to endure large profit losses. The downsizing of the DVD rental service only took place step by step, after Netflix was able to establish themselves as a streaming service. In addition to this, the fact that Netflix focused on one product to a large extent, also plays a major role. Unlike many competitors, Netflix's main product is home entertainment. Companies like Amazon, whose focus is on online shopping, or Apple, who focus on high-end devices, must therefore allocate their resources to various business areas, while Netflix can use them to further develop and expand their service. The reason for the focus on one product is, according to an interview with Reed Hastings, due to one of his mentors who taught him the value of focus 
and that it is better "[...] to do one product well than two products in a mediocre way" (Hastings 2007).

However, these statements are not final. In a recent interview in 2019, Reed Hasting responded to the question about whether Netflix can imagine opening a theme park by saying that it depends on several factors in the future, including how the concept of a theme park will be defined in the future and whether it is consistent with the idea of Netflix (Sarandos 2019).

Points such as these are one of the reasons why Netflix has been able to successfully change their business model twice.

\section{Conclusion}

The study tried to discover how a successful BM Change looks like. In order to find an appropriate answer to this question relevant terms were defined and characteristics in Netflix's behaviour were analyzed, that is, how to a successful enact a BM Change was outlined as well as how the changes influence the company and their economic environment. As a general basis to answer these questions, relevant terms concerning business models were described, followed by a short description regarding Netflix's corporate history.

As it turned out, Netflix passed through two changes: after transitioning from an online-DVD-rental service to a streaming provider, they developed themselves into a content producer. Both changes led to profound changes in the company's business model, which were shown using the BMC. Not only the nine building blocks of the BMC changed but also the selected key figures, the definition of the company's competitors, and its lobbying behaviour. This especially shows the importance of being able to adapt all concerning variables to be successful.

To sum up, it can be said that Netflix is a very dynamic company and dares to leave their well-known environment to focus on future success. As it turned out, the company combined the core capabilities mentioned by Witschel et al. (2019). Both changes were accompanied by time advantages. While other companies still relied on their old business models, Netflix had already begun to plan and execute the next step. The company didn't hold on to previous decisions, was open to change and attempted to use new opportunities. Netflix adapted to the changing market conditions and changed them into a competitive advantage. Moreover, the change was accompanied by restructuring the organisation: the number and type of employees, as well as the departments, changed over time.

\section{Limitations and further research}

Although the presented work provides several insights into the success story of Netflix, the study has certain limitations that should be taken into account when interpreting the findings. As a consequence, the identified limitations outline a starting point for future research.

Firstly, the present study focussed on the path Netflix took but did not analyse how the change within the company was carried out. Future studies should find out how a BM Change can be carried out as successfully as possible from an internal perspective. By surveying this, it should consider implementation steps, the timing of the change and the solution to problem areas. It is also necessary to take a look at the challenges that come along with such a change. A possible problem area can be the resistance of the workforce to a change. The retraining of employees should also be taken into account, as they may face major challenges with the newly required skills.

Secondly, since successful streaming was made possible by increasing bandwidths, it is recommended to analyse technological developments in order to discover potential opportunities and threats to companies like Netflix. Moreover, this working paper did not focus on the competitive perspectives; further studies could appropriately take a closer look at them.

Thirdly, in addition to the company view, it may also be interesting to observe the future of business concepts themselves. What are the trends in the area of BM Change? Also, which concepts are becoming increasingly important and which are being left behind?

Acknowledgements We would like to thank two anonymous reviewers for their suggestions on the article.

\section{Compliance with ethical standards}

Conflict of interest On behalf of all authors, the corresponding author states that there is no conflict of interest.

Open Access Dieser Artikel wird unter der Creative Commons Namensnennung 4.0 International Lizenz veröffentlicht, welche die Nutzung, Vervielfältigung, Bearbeitung, Verbreitung und Wiedergabe in jeglichem Medium und Format erlaubt, sofern Sie den/die ursprünglichen Autor(en) und die Quelle ordnungsgemäß nennen, einen Link zur Creative Commons Lizenz beifügen und angeben, ob Änderungen vorgenommen wurden. Die in diesem Artikel enthaltenen Bilder und sonstiges Drittmaterial unterliegen ebenfalls der genannten Creative Commons Lizenz, sofern sich aus der Abbildungslegende nichts anderes ergibt. Sofern das betreffende Material nicht unter der genannten Creative Commons Lizenz steht und die betreffende Handlung nicht nach gesetzlichen Vorschriften erlaubt ist, ist für die oben aufgeführten Weiterverwendungen des Materials die Einwilligung des jeweiligen Rechteinhabers einzuholen. Weitere Details zur Lizenz entnehmen Sie bitte der Lizenzinformation aufhttp://creativecommons. org/licenses/by/4.0/deed.de. 


\section{References}

Albanese J (2017) The Death of a Toy Retailer: How a Lack of Digital Transformation Helped Destroy Toys "R" Us. https:// www.inc.com/jason-albanese/the-death-of-a-toy-retailer-howa-lack-of-digital-transformation-helped-destroy-toys-r-us.html. Accessed 30 July 2020

Ash A (2020) The rise and fall of Blockbuster. https://www.busin essinsider.com/the-rise-and-fall-of-blockbuster-video-strea ming-2020-1 ?r=DE\&IR=T. Accessed 30 July 2020

Bhasin H (2018) Why Nokia lost its market share? https://www. marketing91.com/nokia-lost-market-share/. Accessed 17 July 2020

Burks R (2019) Netflix Originals Outpaced Acquired Content For First Time In 2018. https://screenrant.com/netflix-originalscontent-comparison/. Accessed 4 Aug 2020

Cinergix Pty. Ltd. (2019) The Easy Guide to the Business Model Canvas. https://creately.com/blog/diagrams/business-model-canva s-explained/. Accessed 17 Aug 2020

Clark T (2020) A chart of Netflix's Oscar nominations each year since 2014 shows how it's taken the movie business by storm. https:// www.businessinsider.com/number-of-netflix-oscar-nomination s-per-year-chart-2020-1?r=DE\&IR=T. Accessed 5 Aug 2020

Cuc JE (2019) Trends in business model research: a bibliometric analysis. J Bus Models 7:1-24

Edspira (2019) Netflix Streaming vs. DVD. https://www.edspira.com/ netflix-streaming-vs-dvd/. Accessed 6 Aug 2020

Elliott M (2019) You Won't Believe How Many Original Movies and Shows Netflix Released in 2019. https://www.cheatsheet.com/ entertainment/you-wont-believe-how-many-original-movies-andshows-netflix-released-in-2019.html/. Accessed 18 Aug 2020

Falcone J (2009) Netflix-compatible video devices compared. https ://www.cnet.com/news/netflix-compatible-video-devices-compa red/. Accessed 24 Aug 2020

Foss NJ, Saebi T (2017) Fifteen years of research on business model innovation. J Manag 43:200-227. https://doi.org/10.1177/01492 06316675927

Fritz B (2011) Netflix confirms deal to offer original content. https:// www.latimes.com/business/la-xpm-2011-mar-19-la-fi-ct-netflixhouse-20110319-story.html. Accessed 27 Aug 2020

Frommer D, Blodget H (2011) Exclusive interview with netflix ceo reed hastings: Netflix's market opportunity is a lot bigger than you think. https://www.businessinsider.com/netflix-ceo-reed-hastingsinterview-2011-4? $\mathrm{r}=\mathrm{DE} \& \mathrm{IR}=\mathrm{T}$. Accessed 6 Aug 2020

Graham M (2018) DVD déjà vu: Redbox is gearing up for its first major campaign. https://adage.com/article/agency-news/amid-turmoildvd-rental-redbox-gearing-major-campaign/314437. Accessed 10 Aug 2020

Hastings R (2005) How I did it: reed hastings, Netflix. https://www. inc.com/magazine/20051201/qa-hastings.html. Accessed 20 Aug 2020

Hastings R (2007) Questions for... Reed Hastings. https://archive.fortu ne.com/magazines/fortune/fortune_archive/2007/05/28/10003 4248/index.htm?section=money_latest. Accessed 20 Aug 2020

Heikkinen A-M (2014) Business model transformation process in the context of business ecosystem. http://jultika.oulu.fi/files/nbnfi oulu-201403131175.pdf

Hossain M (2017) Business model innovation: past research, current debates, and future directions. J Strategy Manag 10:342-359. https://doi.org/10.1108/JSMA-01-2016-0002

Ibarra D, Ganzarain J, Igartua JI (2018) Business model innovation through Industry 4.0: A review. Procedia Manufacturing 22:4-10. https://doi.org/10.1016/j.promfg.2018.03.002
Internet Association (2020) Our Members. https://internetassociation. org/our-members/

Jackson D (2017) The Netflix prize: how a \$1 million contest changed binge-watching forever. https://www.thrillist.com/entertainment/ nation/the-netflix-prize

Keegan R (2019) The Netflix Lobbying Machine: Inside the Effort to Sway Policy Worldwide. https://www.hollywoodreporter.com/ news/netflix-lobbying-machine-inside-effort-sway-policy-world wide-1229622. Accessed 12 Aug 2020

LinkedIn (2020) Netflix company profile. https://www.linkedin.com/ company/netflix/people/. Accessed 3 Aug 2020

Littleton C (2020) Disney plus reaches 28.6 million subscribers, Hulu Hits 30.4 Million. https://variety.com/2020/tv/news/disney-plusreaches-26-5-million-subscribers-1203492187/. Accessed 10 Aug 2020

Lovely S (2019) How many titles are available on netflix in your country? https://cordcutting.com/blog/how-many-titles-are-availableon-netflix-in-your-country/. Accessed 24 Aug 2020

Macaulay T (2018) Ten years on: How Netflix completed a historic cloud migration with AWS. https://www.computerworld.com/artic le/3427839/ten-years-on--how-netflix-completed-a-historic-cloud -migration-with-aws.html. Accessed 24 July 2020

Mauldin A (2019) 466 Tbps: the global internet continues to expand. https://blog.telegeography.com/466-tbps-the-global-internet-conti nues-to-expand. Accessed 10 Aug 2020

MPAA (2020) Who we are. https://www.motionpictures.org/who-weare/. Accessed 20 Aug 2020

Murph D (2008) Starz Play content added to Netflix's streaming library. https://www.engadget.com/2008-10-01-starz-play-content-added -to-netflixs-streaming-library.html. Accessed 14 Aug 2020

Netflix Inc (2002a) Fellow Shareholder - annual Report 2002. https:// www.netflixinvestor.com/financials/annual-reports-and-proxies/ default.aspx. Accessed 3 Aug 2020

Netflix Inc (2002b) Netflix annual report 2002. https://www.netflixinv estor.com/financials/annual-reports-and-proxies/default.aspx. Accessed 3 Aug 2020

Netflix Inc (2007) Netflix Annual Report 2007. https://www.netflixinv estor.com/financials/annual-reports-and-proxies/default.aspx. Accessed 3 Aug 2020

Netflix Inc (2011) Netflix annual report 2011. https://www.netflixinv estor.com/financials/annual-reports-and-proxies/default.aspx. Accessed 3 Aug 2020

Netflix Inc (2013) Netflix annual report 2013. https://www.netflixinv estor.com/financials/annual-reports-and-proxies/default.aspx. Accessed 5 Aug 2020

Netflix Inc (2018) Netflix annual report 2018. https://www.netflixinv estor.com/financials/annual-reports-and-proxies/default.aspx. Accessed 6 Aug 2020

Netflix Inc (2020) Netflix media center: about netflix. https://media .netflix.com/en/about-netflix. Accessed 12 Aug 2020

Nielsen C, Lund M (2014) A brief history of the business model concept. https://vbn.aau.dk/ws/portalfiles/portal/209076882/ NOTAT_A_Brief_History_of_the_Business_Model_Concept.pdf. Accessed 5 Aug 2020

Ode KA, Wadin JL (2019) Business model for sutstainability - change in dynamic environments. J Bus Model 7:13-38

Osterwalder A, Pigneur Y, Clark T (2010) Business model generation: a handbook for visionaries, game changers, and challengers. Wiley, Hoboken, NJ

Ovans A (2015) What is a business model? https://hbr.org/2015/01/ what-is-a-business-model. Accessed 7 Aug 2020

Pepitone J (2011) Netflix's Canada problem. https://money.cnn. com/2011/05/17/technology/netflix_canada/index.htm?iid=EL. Accessed 25 Aug 2020 
Pogue D (2005) In the competition for DVD rentals by mail, two empires strike back. https://www.nytimes.com/2005/03/31/techn ology/circuits/in-the-competition-for-dvd-rentals-by-mail-twoempires.html. Accessed 27 Aug 2020

Rachinger M, Rauter R, Müller C, Vorraber W, Schirgi E (2019) Digitalization and its influence on business model innovation. JMTM 30:1143-1160. https://doi.org/10.1108/JMTM-01-2018-0020

Redbox (2020) About Us. http://about.redbox.com/about-redbox/. Accessed 21 August 2020

Reid J (2017) 'The White Helmets' Wins the first oscar for Netflix. https://decider.com/2017/02/26/netflix-first-oscar-the-white -helmets/. Accessed 17 Aug 2020

Rissanen T, Ermolaeva L, Torkkeli L, Ahi A, Saarenketo S (2020) The role of home market context in business model change in internationalizing SMEs. EBR 32:257-275. https://doi.org/10.1108/ EBR-09-2018-0168

Roettgers J (2013) Netflix wants to spend up to 15 percent of its content cash on originals. https://gigaom.com/2013/05/30/netflix-wants -to-spend-up-to-15-percent-of-its-content-cash-on-originals/. Accessed 24 Aug 2020

Sarandos T (2019) The future of the small screen: Netflix and the streaming revolution. https://www.aspeninstitute.org/events/morri s-series-lecture-future-of-pop-culture-with-ted-sarandos-in-conve rsation-with-derek-thompson/. Accessed 27 Aug 2020

Schedeen J (2019) Here's how much money netflix spends on content compared to disney. https://www.ign.com/articles/2019/08/08/ disney-outspending-netflix-streaming-original-content-budget

Schorn D (2006) The brain behind netflix. https://www.cbsnews.com/ news/the-brain-behind-netflix/. Accessed 23 July 2020

Seidenstricker S, Ardilio A (2017) Business-model-oriented technology management for emergent technologies. In: Khosrow-Pour M (ed) Encyclopedia of information science and technology, 4th edn. IGI Global, Hershey, pp 4560-4569
Seidenstricker S, Allegretti S, Kasseckert A (2018) Factors for success in business model innovation. JSIS 13:10-32. https://doi.org/https ://doi.org/10.33423/jsis.v13i5.158

Solsman JE (2020) Netflix led the 2020 Oscars in nominations. It won 2 awards. https://www.cnet.com/news/netflix-oscars-two-wins-laura -dern-american-factory-scorecard/. Accessed 11 Aug 2020

Spangler T (2019) Netflix Spent $\$ 12$ Billion on Content in 2018. Analysts Expect That to Grow to $\$ 15$ Billion This Year. https://varie ty.com/2019/digital/news/netflix-content-spending-2019-15-billi on-1203112090/. Accessed 25 Aug 2020

Steel E (2015) Netflix is betting its future on exclusive programming. https://www.nytimes.com/2015/04/20/business/media/netflix-isbetting-its-future-on-exclusive-programming.html. Accessed 11 Aug 2020

Teece DJ (2018) Business models and dynamic capabilities. Long Range Plan 51:40-49. https://doi.org/10.1016/j.lrp.2017.06.007

Tyler T (2020) 7 Metrics to help you measure success and ROI in a fleet business. https://www.verizonconnect.com/resources/article/ how-to-measure-business-success/. Accessed 5 Aug 2020

Witschel D, Döhla A, Kaiser M, Voigt K-I, Pfletschinger T (2019) Riding on the wave of digitization: insights how and under what settings dynamic capabilities facilitate digital-driven business model change. J Bus Econ 89:1023-1095. https://doi.org/10.1007/s1157 3-019-00950-5

Yglesias M (2013) Netflix's race to become a content producer before the producers swallow netflix. https://slate.com/business/2013/06/ netflix-original-content.html. Accessed 10 Aug 2020

Young S (2018) 5 key benefits of using a business model canvas instead of a business plan. https://medium.com/@chimera.swa/5-keybenefits-of-using-a-business-model-canvas-instead-of-a-busin ess-plan-55d5d727ba46. Accessed 31 July 2020 